\title{
Trade Openness, Economic Growth and Competitiveness. The Case of the Central and Eastern European Countries
}

\section{Vaida Pilinkiene}

\author{
Kaunas University of Technology \\ K. Donelaicio st. 73, LT-44029, Kaunas, Lithuania \\ E-mail.vaida.pilinkiene@ktu.lt
}

cross $^{\text {ref }}$ http://dx.doi.org/10.5755/j01.ee.27.2.14013

\begin{abstract}
This article examines the effects of trade openness on the economic growth and competitiveness of Central and Eastern European countries (CEEs). Although CEEs are characterised by high indicators of trade openness, they show rather different trends of economic development and competitiveness. In most CEEs, trade policies are oriented towards regional trade cooperation with an explicit aim of integration in global economics. The empirical research was conducted on the basis of the panel data for 11 CEEs over the period 2000 to 2014 by applying correlation analysis. Granger-causality test and vector autoregression (VAR) model. This methodological framework allows to test the direct causality relations among trade openness, economic growth and competitiveness, and enables to distinguish between short-run and long-term effect. The research results have confirmed the empirical interdependence among the triad components - trade openness, economic growth and competitiveness, i.e. it has been established that economic growth leads to the improvement of trade openness, while competitiveness of the CEE region leads to the improvement of economic growth, which has obviously disclosed the validity of the theoretical insights. Granger-causality test as well as the developed VAR model have revealed that economic growth has a long-lasting effect on trade openness, while the indicators of competitiveness have a longlasting effect on GDP per capita in CEEs.
\end{abstract}

Keywords: Trade Openness, Economic Growth, Competitiveness, Central and Eastern European Countries.

\section{Introduction}

Increasing flows of international trade as well as strong impact of globalisation determine the changes in economic growth and competitiveness of different countries. The degree of international trade liberalisation and trade openness is also conditioned by economic integration agreements such as the European Union (EU), North American Free Trade Agreement (NAFTA) and targeted activities of international economic organisations, e.g. World Trade Organization (WTO). It is obvious that both large and small economies are dependent on other players in international markets. This raises the question to which extent trade openness of different countries contributes to their economic growth and competitiveness, and what impact this interrelation has on economics.

The Central and Eastern European Countries (CEEs) are experiencing high growth rates in terms of trade openness. The total trade openness index for CEEs in 2014 reached 136,4 percent, and in comparison to 2000 increased by 45 percent. Slovak Republic (trade openness index is equal to $180 \%)$, Estonia $(167 \%)$ and Lithuania $(163 \%)$ are attributed to CEEs countries with the highest degree of trade openness whereas Romania (82\%) and Poland $(78 \%)$ show the lowest degrees in this respect (European Chamber, 2015).It is important to note that trade openness index for the least trade open CEEs is equal to the average of the EU $(81,3 \%)$, which proposes that the old EU member-states are much more closed for international trade, but have higher degree of competitiveness. With reference to the data of World Economic Forum, in 2014 Germany, one of the most competitive EU states, occupied 5th position in the global ratings by its Global Competitiveness Index, but had trade openness index equal to 85 percent, i.e. slightly higher than the EU average. Hence, it is purposeful to research whether higher degree of country's competitiveness leads to lower degree of trade openness and vice versa, and define the conditions for this interrelation.

Although literature nexus provides a sufficiently comprehensive view of the impact of trade openness on country's economic growth and competitiveness, interrelationship of these three variables still remains an open and a discussable topic among scholars. With regard to a theoretical relationship between trade openness and economic growth, most of the studies (Dollar \& Kraay, 2003; Gries \& Redlin, 2012; Tahir \& Azid, 2015; Musila \& Yiheyis, 2015) confirm it to be positive. As it was noted by Taylor et al. (1993), Duczynski (2000) and Sarkar (2008), more openness countries have a greater ability to catch up to leading technologies. Chang et al. (2009) and Ulasan (2012) propose that trade openness contributes to more efficient distribution of resources, and allows to exploit country's competitive advantages. Miller \& Upadhyay (2000), Xu et al. (2008) confirm that trade openness allows the dissemination of knowledge and human skills. The research on the linkages between trade openness and competitiveness revealed that the impact of trade openness was irregular, and depended on the prevalent economic theories (neoclassical, Keynesian, etc.). Later studies, where trade openness was treated as one of the 
determinants of competitiveness (Guerrieri \& Meliciani, 2005; Snieska \& Draksaite, 2007; Berger, 2008; Staskeviciute \& Tamosiuniene, 2010; Bruneckiene \& Paltanaviciene, 2012; Mulatu, 2016), and linkages between competitiveness and indicators of productivity were analysed in the context of international trade liberalisation (Miller \& Upadhyay, 2000; Kim, 2000; Damijan et al., 2009; Paul \& Marks, 2009; Liu \& Nishijima; 2012; Rath \& Parida, 2014), were directed towards compatibility between competitiveness and social welfare. On the other hand, it is argued that indicators of productivity should not be considered while assessing competitiveness conditions and changes (Krugman, 1996; Reinert, 1995; Reiljan et al., 2000; Hwang \& Wang, 2004). Empirical studies often confirm positive linkages among trade openness, economic growth and competition indicators. Nevertheless, the weakness of such studies lies in the lack of the causality between the triad of trade openness, competitiveness and economic growth on cross-country level. Most of studies investigate the relationship on a certain country level for time series data, but cross-country investigations, based on application of panel models, are hardly performed. The aim of this paper is to examine the causal links among trade openness, economic growth, and competitiveness in 11 CEE countries over the period 2000-2014. The methods of the research include a comparative literature analysis, correlation analysis, Granger-causality test and vector autoregression (VAR) model.

\section{Theoretical and Empirical Background}

Previous studies reveal that internationally active countries are much more productive and competitive in comparison to those producing and acting exceptionally in the local market. International trade has a positive impact on the efficiency of resource allocation and determines faster economic growth, which may transform into a greater factor accumulation, in particular in the countries with technology diffusion and knowledge spillovers.

Trade openness and economic growth. Trade openness usually refers to a unit of country's economic policy measurement, also expressed as trade openness index, which is estimated as a sum of exports and imports of goods and services measured as a share of gross domestic product. Furthermore, trade openness is defined as reduction of policy barriers to international trade rather than trade intensity (Ulasan, 2012). Although trade openness is influenced by such factors as country size, duty level, transportation costs or distance to trade partners, export and import volumes remain the key constituents that most precisely depict the level of trade openness.

Positive impact of trade openness on the scopes of economic growth has been confirmed in numerous scientific studies (Yanikkaya, 2003; Dollar \& Kraay, 2003; Sarkar, 2008; Chang et al., 2009; Ulasan, 2012; Gries \& Redlin, 2012; Musila \& Yiheyis, 2015; Tahir \& Azid, 2015). According to the endogenous growth theory, a liberal trade mode generates benefits to the industries with an obvious competitive advantage (Rebelo 1991, Romer 1994). In addition, this theory proves that faster economic growth can be achieved through specialisation and the reduction of product unit costs. Taylor et al., (1993),
Duczynski (2000) note that the countries with higher level of trade openness have better opportunities to exploit technological innovations, which also determines a faster pace of their economic growth.

With reference to transaction cost theory, markets for intermediary products are usually imperfect; thus, trade partners bear transaction costs while operating in international markets (Williamson, 1998; Macher \& Richman, 2008). It is important to note that transaction costs can be minimized if countries are opened for trade, i.e. if they apply a rather liberal trade mode in respect of their trade partners. In fact, any mode (integration, liberalisation, etc.) allows to developing economies to minimizetrade transaction costs, increase availability of international markets, guarantee the appropriate level of foreign reserves, and reduce transaction costs of investment (Remneland-Wikhamn \& Knights, 2012).

According to the product life cycle theory, having standardized product technologies, companies tend to relocate their production to the countries with comparatively low capital intensity (Hirsch, 2009; Farmer \& Schelnast, 2012). In other words, the higher is innovation rate in leading economies, the faster pace of economic growth can be achieved via imitation for laggard economies (Adhikary, 2010). It is because advanced innovations and technologies flow from the leading economies to followers via trade openness. What is more, greater rate of innovation and technology absorptions promote the raise of human resources skills and abilities, which, in turn, leads to economic growth during the long run.

Many empirical studies confirm positive relationship between trade openness and economic growth effects, but the size of these effects can be different. Gries \& Redlin (2012), who researched the links between trade openness and GDP per capita growth in 158 countries during the period of 1970-2009, established a long-run relationship between trade openness and economic growth with a shortrun adjustment to the deviation from the equilibrium for both directions of dependency. Musila \& Yiheyis (2015) found that trade openness positively affected economic growth in Kenya over the period 1961-2009. Granger's Causality tests showed that a change in trade openness influences the long-term rate of economic growth through the interaction with physical capital growth. Nevertheless, some empirical studies disclose negative links between trade openness and long-term rate of growth. Having analysed so-called "Tariff-Growth Paradox", Clemens \& Williamson (2001) established a negative relationship between trade openness and economic growth, which emerges due to application of different tariffs between the trade partners. Abbas (2014) analysed the impact of trade openness and liberalisation on economic growth in developing countries during the period of 1990-2011 using the panel fixed effect model. The results showed that trade liberalization has a negative impact on economic growth of the selected countries whereas real exports make a significant positive impact on it.

Trade openness and competitiveness. Trade openness is a ground of economic growth, workplace creation, and country's welfare development (Dowrick, 2004; Singh, 2015). Nevertheless, trade openness alone does not lead to success. Country's competitiveness in respect of international 
trade is treated as its ability to convert the potential created by access to global markets into the opportunities and prospects offered to domestic businesses, households and population. The success of this conversion depends on: 1) country's economic policy and instruments; 2) the degree of institutional transparency and reliance on public authorities; 3) local politicians' comprehension of how policies and institutions interact to affect competitiveness (World Economic Forum, 2015).

What are the roots of the relationship between competitiveness and trade openness? Following the attitudes of neoclassical economics, international trade is based on comparative advantage, which, in principle, determines the emergence of a positive impact on trading countries in case they specialise their production and export. Such attitude gradually replaced the theory of "zero-sum", which prevailed in the period of mercantilism. Neoclassics performed simplified analyses on competitiveness and international trade by eliminating the variety of market structures, labour force movement restrictions, possibilities of technical progress, and differences in consumer needs. With reference to Keynesian economics, trade openness is a precondition of the intensity of competition and export revenues. On the other hand, the efficiency of trade openness is, to a large extent, determined by the appropriate governmental politics. Seeking to integrate the ideas of various economic schools, Porter (1990) introduced a systemic model of competitiveness referred to as "Diamond" model, following which competitiveness is perceived as an ability of a country to create the environment that promotes business improvement and innovation absorption faster than in foreign countries. The scholar also extended the concept of competitiveness by stating that it covers a variety of determinants. Productivity was appointed as the main determinant of the growth of national economics.

Compatibility between competitiveness and social welfare inspires country's ability to ensure high standards of living for its population, while trade openness and relevant factors are treated as the main determinants of competitiveness (Staskeviciute \& Tamosiuniene, 2010). Nevertheless, most authors (Guerrieri \& Meliciani, 2005; Snieska \& Draksaite, 2007; Berger, 2008, Mulatu, 2016) agree that country's ability to create or recreate social welfare, i.e. the ability to export and develop macroeconomic attractiveness and productivity, is much more important than the welfare itself. Productivity is considered to be one of the most significant determinants of country's competitiveness and living standard growth. According to Porter (1990), country's ability to ensure high living standards for its population ultimately depends on industrial and business productivity. In other words, a country with low degree of productivity cannot be treated as competitive.

On the other hand, scientific literature contains opposing views. Reinert (1995) and Reiljan et al. (2000) argue that country's competitiveness does not depend on the location where staff income is generated, i.e. it does not depend on whether staff income is generated in foreign or local markets. In addition, the authors propose to eliminate the factor of productivity since particular countries, for instance, China, are successful exporters with comparatively low degree of competitiveness, while the old EU member-states show high productivity rates although their trade openness indicators are much lower in comparison to Chinese. Hence, high productivity not necessarily leads to an increase in country's competitiveness.

In spite of some contradictions, the largest part of empirical studies analyse the linkage between trade openness and competitiveness as of the main determinants of the latter, and the factor of productivity is included in the analysis. However, the results of the empirical research on the linkage between trade openness and productivity are rather variant. Most scholars (Miller \& Upadhyay, 2000; Damijan et al., 2009; Paul \& Marks, 2009; Liu \& Nishijima; 2012) find a significant positive relationship between the variables mentioned above. For instance, in their study on the drivers behind China's economic growth in 29 China's provinces during the period 1994-2006, Xu et al. (2008) found that trade openness is one of the key determinants of total factor productivity, but its importance varies with technological levels of provinces. Kim (2000) researched the impact of trade openness and liberalisation on competitiveness, productivity and scale efficiency in 36 Korean industrial enterprises for the period of 1966 to 1988. The results of the research confirmed positive links among the researched variables. While analysing the impact of trade openness on total factor productivity for 5 South Asian countries during the period from 1980 to 2011 and using the panel cointegration and Granger causality techniques, Rath \& Parida (2014) established positive links between the variables. The results of the research revealed that trade reforms, licensing policy, reduction or elimination of trade barriers in the researched South African countries significantly increased their trade openness and productivity in the short run. Dovis \& Milgram-Baleix (2009), who analysed the impact of competitiveness on productivity of Spanish manufacturing firms in the context of trade liberalisation, established a negative link between productivity and international trade tariffs. What is more, it was found that higher degree of competitiveness has a positive impact on productivity in case trade tariffs are eliminated. Some other studies revealed the reverse effects. For instance, Hwang \& Wang (2004), who researched the impact of trade openness on total factor productivity for 45 Japanese manufacturing industries in period of 1973-1998, did not confirm the hypothesis of "the virtuous cycle of trade and growth." Despite the variety of scientific interpretations concerning the links between competitiveness and trade openness, it can be stated that interrelation between competitiveness and trade openness is plausible as production increasingly overgrows borders, and the spillover effects of domestic policies multiply in number and size. Trade openness, determined by the agreements of economic integration or trade discounts, develop into the wide range of policies that shape a country's competitiveness in the global markets. Cross-border agreements on trade transactions are grounded on the rules on investment, intellectual property, public procurement, state-owned enterprises, competition policy transparency, environmental regulation and labour standards. That shows, that international trade agreements stopped being only about tariffs and market access rules years ago. 


\section{Research Methodology}

Three following techniques will be applied for the analysis of the linkages among trade openness, economic growth and competitiveness: correlation analysis; Grangercausality test and Vector autoregression (VAR) model.

Correlation analysis will be performed by calculating Pearson's correlation coefficient (r) (Kane, 2003). In order to test the significance of linear relationship between the variables, the following hypothesis will be tested: $\mathrm{H}_{0}$ : $r_{x y}=0, \quad H_{1}: r_{x y} \neq 0$. The hypothesis will be tested by calculating Student $(t)$ statistics and estimating the probability for Student's t-distribution. The estimated probability will be compared with the selected level of significance, which is equal to 0,05 . It indicates a $5 \%$ risk that hypothesis $\mathrm{H}_{0}$ will be rejected. The significance of Pearson's correlation coefficient will be assessed in compliance with the following rule: if estimated probability is lower than 0,05 , linear relationship between

the variables is significant, and if probability is higher than 0,05 , linear relationship between variables is insignificant.

The linkages among trade openness, economic growth and competitiveness may appear to be not only contemporaneous. Hence, Granger-causality test will be carried out in order to verify any potential delayed effects. Granger-causality discloses which part of the current y can be explained by y past values, and reveals whether addition of the lagged values of $x$ can improve the explanation of $y$. Variable y is considered to be Granger-caused by variable $x$ in case $x$ contributes to the prediction of $y$, or, equivalently, in case the coefficients of the lagged $x$ are statistically significant (Granger, 2007; Swanson, 2010).

The data of three previous years (i.e. three lags of variables) will be examined. Considering data specificity (the analysis will be based on the panel data set), a Granger-causality testing, specific to this particular type of data, will be employed. The bivariate regressions in the panel data context will take the following forms:

$$
\begin{aligned}
& y_{i, t}=\alpha_{0, i}+\alpha_{1, i} y_{i, t-1}+\alpha_{2, i} y_{i, t-2}+\alpha_{3, i} y_{i, t-3}+\beta_{1, i} x_{i, t-1}+\beta_{2, i} x_{i, t-2}+\beta_{3, i} x_{i, t-3}+\varepsilon_{i, t} \\
& x_{i, t}=\alpha_{0, i}+\alpha_{1, i} x_{i, t-1}+\alpha_{2, i} x_{i, t-2}+\alpha_{3, i} x_{i, t-3}+\beta_{1, i} y_{i, t-1}+\beta_{2, i} y_{i, t-2}+\beta_{3, i} y_{i, t-3}+\varepsilon_{i, t} .
\end{aligned}
$$

In the formulas above, $t$ denotes time period dimension of the panel; $i$ denotes the cross-sectional dimension; $y_{i, t-l}$ and $x_{i, t-l}$ denote the variables with lags $(l=0, \ldots, 3) ; \alpha_{l, I}$ and $\beta_{l,}$ denote the parameters of the model; finally, $\varepsilon_{i, t}$ denotes an error of the model. The panel data will be treated as a single large stacked data set. Granger-causality test will be performed in the standard way, with the exception of data entrance from one cross-section to the lagged values from the next cross-section. This method assumes that all the coefficients remain the same across all the cross-sections.
Hypothesis $H_{0}$ proposes that $x$ does not Granger-cause $y$ in regression (1), and $y$ does not Granger-cause $x$ in regression (2).

Finally, the linkages between the indicators will be described by VAR model, which will be developed with reference to the results of the correlation analysis and Granger-causality test. The general form of VAR model, when the lag period is not longer than 3 , can be expressed as follows:

$$
\begin{aligned}
& y_{i, t}=\alpha_{0}+\alpha_{1} y_{i, t-1}+\alpha_{2} y_{i, t-2}+\alpha_{3} y_{i, t-3}+\beta_{0,1} x_{l, t}+\beta_{1, l} x_{1, t-1}+\beta_{2,1} x_{1, t-2}+\beta_{3, l} x_{1, t-3}+\beta_{0,2} x_{2, t}+\beta_{1,2} x_{2, t-1}+\beta_{2,2} x_{2, t-2}+\beta_{3,2} x_{2, t-3}+\ldots+\beta_{0, l} x_{l, t}+ \\
& \beta_{1, l} x_{l, t-1}+\beta_{2, l} x_{l, t-2}+\beta_{3, l} x_{l, t-3}+\varepsilon_{t}
\end{aligned}
$$

\section{Research Results}

The research is based on the annual data for 11 countries from Central and Eastern Europe (Bulgaria, Croatia, the Czech Republic, Estonia, Hungary, Latvia, Lithuania, Poland, the Slovak Republic, Slovenia and Romania) over the period of 2000-2014. The data for the research was extracted from the World Bank national accounts as well as from OECD national account data files. This paper focuses on the linkages among three groups of macroeconomic indicators: trade openness, economic growth and competitiveness. Trade openness is described by trade openness index (Trade), which is equal to the sum of exports and imports of goods and services measured as a share of GDP. Economic growth is characterized by two indicators, i.e. annual GDP growth (GDP_growth) in percentages and current GDP per capita (GDP_capita) in
USA dollars. According to review of theoretical research (Guerrieri \& Meliciani, 2005; Mauro \& Forster, 2008; Dovis et al, 2009; Mulatu, 2016) the competitiveness usually described by indicators reflecting price/costs efficiency (investment, R\&D, export/import) and productivity growth (labour, value added, etc.). Thus, competitiveness is considered to be described by five following indicators: 1) Foreign direct investment (FDI), net inflows (\% of GDP); 2) Research and development expenditure (R\&D) (\% of GDP); 3) Services value added (Services_VA) (\% of GDP); 4) Industry value added (Industry_VA) (\% of GDP); 5) Labour productivity (Labour_PROD) per hour worked (euro per hour worked). The analysis has been performed with software EViews 8.

\begin{tabular}{|c|c|c|c|c|c|}
\hline Indicator & Mean & Median & Maximum & Minimum & Std. Dev. \\
\hline FDI & 5,392046 & 3,867496 & 50,78472 & $-16,0911$ & 6,783299 \\
\hline GDP_capita & 11392,07 & 11363,42 & 27501,81 & 1609,281 & 5808,004 \\
\hline GDP_growth & 3,278076 & 3,835605 & 11,90219 & $-14,8142$ & 4,423481 \\
\hline Industry_VA & 30,74179 & 30,45909 & 38,62386 & 22,87112 & 3,799938 \\
\hline Labour_PROD & 9,382424 & 8,900000 & 21,50000 & 3,000000 & 4,144022 \\
\hline R\&D & 0,895637 & 0,784210 & 2,586890 & 0,322550 & 0,477899 \\
\hline Services_VA & 64,67757 & 64,36446 & 73,37468 & 56,14105 & 3,572663 \\
\hline TRADE & 113,5357 & 113,7411 & 183,4276 & 58,07425 & 31,73762 \\
\hline
\end{tabular}
Descriptive statistics of the macroeconomic indicators have been provided in Table 1 .

Descriptive Statistics of Macroeconomic Indicators

Source: compiled by the author 
The average annual GDP_growth across the sample countries accounted for 3,3 \% during 2000-2014. However, the variability is rather substantial as the coefficient of variation (standard deviation divided by mean) exceeds $100 \%$. This is because the analysed period includes the global financial crisis, when the GDP growth was negative. Large variability is also typical of foreign direct investment (FDI), which showed substantial fluctuations (from 50,8 to -16.1) in Hungary. This is also the reason why FDI is the only indicator with the median that significantly differs from the mean. The average annual TRADE across the sample countries composed 114
$\%$ during 2000-2014. It is characterized by lower variability. Services value added is the most stable indicator with the average value of $64,7 \%$. Further in the research, the linkages among trade openness, economic growth and competitiveness were analysed by calculating Pearson's correlation coefficient between each pair of the macroeconomic indicators. The results have been presented in Table 2. The second number in the Table 2 shows the significance probablity of correlation coefficient. If the probability is lower 0,05 thus the correlation coefficient is significant.

The Results of the Correlation Analysis

Table 2

\begin{tabular}{|c|c|c|c|c|c|c|c|c|}
\hline & TRADE & GDP_growth & GDP_capita & FDI & R\&D & Services_VA & Industry_VA & Labour_PROD \\
\hline \multirow{2}{*}{ TRADE } & 1 & & & & & & & \\
\hline & 0,000 & & & & & & & \\
\hline \multirow{2}{*}{$\begin{array}{l}\text { GDP } \\
\text { growth }\end{array}$} & $-0,008$ & 1 & & & & & & \\
\hline & 0,917 & & & & & & & \\
\hline \multirow{2}{*}{$\begin{array}{l}\text { GDP } \\
\text { capita }\end{array}$} & 0,575 & $-0,303$ & 1 & & & & & \\
\hline & 0,000 & 0,000 & & & & & & \\
\hline \multirow{2}{*}{ FDI } & 0,102 & 0,175 & $-0,132$ & 1 & & & & \\
\hline & 0,193 & 0,024 & 0,092 & & & & & \\
\hline \multirow{2}{*}{ R\&D } & 0,488 & $-0,220$ & 0,709 & $-0,095$ & 1 & & & \\
\hline & 0,000 & 0,004 & 0,000 & 0,223 & & & & \\
\hline \multirow{2}{*}{ Services_VA } & $-0,100$ & $-0,207$ & 0,069 & $-0,021$ & $-0,031$ & 1 & & \\
\hline & 0,199 & 0,008 & 0,378 & 0,785 & 0,694 & & & \\
\hline \multirow{2}{*}{ Industry_VA } & 0,346 & 0,063 & 0,354 & $-0,045$ & 0,347 & $-0,793$ & 1 & \\
\hline & 0,000 & 0,424 & 0,000 & 0,569 & 0,000 & 0,000 & & \\
\hline \multirow{2}{*}{ Labour_PROD } & 0,521 & $-0,201$ & 0,837 & $-0,156$ & 0,795 & $-0,123$ & 0,534 & 1 \\
\hline & 0,000 & 0,010 & 0,000 & 0,045 & 0,000 & 0,114 & 0,000 & \\
\hline
\end{tabular}

Source: compiled by the author

According to the results, TRADE significantly correlates with the single indicator of economic growth, i.e. GDP_capita, and with three indicators of competitiveness, i.e. R\&D, Industry_VA and Labour_PROD. As the correlation is positive, it means that the increase in economic growth and competitiveness of the CEE region positively influences TRADE.

No uniform conclusion can be made concerning the linkages between the indicators of economic growth and the ones of competitiveness. GDP_growth has a significant positive correlation with FDI, and a significant negative correlation with R\&D, Services_VA and Labour_PROD. The negative correlation between these indicators can be explained by different trends, i.e. recently, GDP has shown much slower growth in comparison to the one observed a decade ago, while the variables of R\&D, Services_VA and Labour_PROD have had an upward trend. It has been found that GDP_capita and GDP_growth are negatively correlated, which can be explained by the fact that it is difficult to increase GDP_capita (as well as Labour_PROD since it is strongly correlated with GDP_capita) than low GDP_capita. For this reason, the CEE countries with high GDP_capita record less significant GDP_growth in comparison to the countries with low GDP_capita. Meanwhile, GDP_capita is significantly and positively correlated with R\&D, Industry_VA and Labour_PROD. This leads to the conclusion that, in a general sense, competitiveness has a positive impact on economic growth of the CEE countries.
The linkages among trade openness, economic growth and competitiveness will be further analysed by performing Granger-causality test between each pair of the indicators:

- between trade openness and economic growth: TRADE $\leftrightarrow$ GDP_capita, TRADE $\leftrightarrow$ GDP_growth;

- between trade openness and competitiveness:

TRADE $\leftrightarrow$ FDI, TRADE $\leftrightarrow$ R\&D,

RADE $\leftrightarrow$ Services_VA, TRADE $\leftrightarrow$ Industry_VA, TRADE $\leftrightarrow$ Labour_PROD;

- between economic growth and competitiveness: GDP_capita $\leftrightarrow$ FDI, GDP_capita $\leftrightarrow$ R\&D,

GDP_capita $\leftrightarrow$ Services_VA

GDP_capita $\leftrightarrow$ Industry_VA,

GDP_capita $\leftrightarrow$ Labour_PROD; GDP_growth $\leftrightarrow$ FDI, GDP_growth $\leftrightarrow R \& D$,

GDP_growth $\leftrightarrow$ Services_VA,

GDP growth $\leftrightarrow$ Industry_VA,

GDP_growth $\leftrightarrow$ Labour_PROD.

In addition, Granger-causality test between GDP_capita and GDP_growth will be performed with a view to improving VAR model.

The results of Granger-causality test according to the lag value $(l=1,2,3)$ at the significant level of 0,05 have been presented in Table 3. A forward arrow $(\rightarrow)$ means that $y$ Granger-causes $x$, whereas a backward arrow $(\leftarrow)$ shows that $x$ Granger-causes $y$; finally, a double-sided arrow $(\leftrightarrow)$ denotes that $x$ and $y$ are interrelated, i.e. $y$ Granger-causes $x$, and $x$ Granger-causes $y$. 
Table 3

The Results of Granger-Causality Test

\begin{tabular}{|c|c|c|c|}
\hline Economic indicators $(y \leftrightarrow x)$ & $l=1$ & $l=2$ & $l=3$ \\
\hline TRADE $\leftrightarrow$ GDP_capita & $\rightarrow$ & $\leftrightarrow$ & $\leftarrow$ \\
\hline TRADE↔GDP_growth & $\leftarrow$ & $\leftarrow$ & $\leftrightarrow$ \\
\hline TRADE $\leftrightarrow$ FDI & $\leftarrow$ & & \\
\hline TRADE↔R\&D & & & $\rightarrow$ \\
\hline \multicolumn{4}{|l|}{ TRADE $\leftrightarrow$ Services_VA } \\
\hline \multicolumn{4}{|l|}{ TRADE↔Industry_VA } \\
\hline TRADE↔Labour_PROD & $\rightarrow$ & & $\leftarrow$ \\
\hline \multicolumn{4}{|l|}{ GDP_capita↔FDI } \\
\hline GDP_capita $\leftrightarrow R \& D$ & $\rightarrow$ & $\leftrightarrow$ & $\leftrightarrow$ \\
\hline GDP_capita $\leftrightarrow$ Services_VA & & $\rightarrow$ & $\rightarrow$ \\
\hline GDP_capita $\leftrightarrow$ Industry & $\leftarrow$ & $\leftrightarrow$ & $\rightarrow$ \\
\hline GDP_capita $\leftrightarrow$ Labour_PROD & $\leftrightarrow$ & $\leftrightarrow$ & $\leftrightarrow$ \\
\hline \multicolumn{4}{|l|}{ GDP_growth↔FDI } \\
\hline GDP_growth $\leftrightarrow R \& D$ & & $\rightarrow$ & $\rightarrow$ \\
\hline GDP_growth $\leftrightarrow$ Services_VA & & $\leftrightarrow$ & $\leftrightarrow$ \\
\hline GDP_growth $\leftrightarrow$ Industry & & $\rightarrow$ & \\
\hline GDP_growth $\leftrightarrow$ Labour_PROD & & & $\rightarrow$ \\
\hline GDP_growth $\leftrightarrow$ GDP_capita & $\leftrightarrow$ & $\leftrightarrow$ & $\leftrightarrow$ \\
\hline
\end{tabular}

Source: compiled by the author

With reference to Granger-causality test results, no causal linkages between TRADE and Services_VA, TRADE and Industry_VA, GDP_capita and FDI, and GDP_growth and FDI have been found. The evident longlasting interrelation exists between GDP_capita and Labour_PROD, as well as between GDP_growth and GDP_capita. Meanwhile, the linkages between the other pairs of the indicators have been changing over the time. Considering the longest period (when lag is equal to 3 ), TRADE Granger-causes R\&D, while Labour_PROD and GDP_capita Granger-cause TRADE at the significant level of 0,05 . Reciprocal linkage exists between TRADE and GDP_growth. GDP_capita Granger-causes Services_VA and Industry_VA, while GDP_growth Granger-causes R\&D and Labour_PROD. Such results suggest that economic growth has a lasting effect on the researched indicators of competitiveness. In addition, reciprocal linkage exists between GDP_capita and R\&D, GDP_capita and Labour_PROD, and GDP_growth and Services_VA. All this leads to the conclusion that trade openness, economic growth and competitiveness are interrelated.

Relationship between the researched macroeconomic indicators was described by VAR model, following which three equations were developed: (1) TRADE is a dependent variable, (2) GDP_capita is a dependent variable, and (3) GDP_capita is a dependent variable. The indicators that showed a significant correlation with a dependent variable at the same (current) period of time (according to the results of the correlation analysis) and had significant lagged values of the variables (according to the results of Granger-causality test) were taken as independent variables. Three lags of each dependent variable were also included.

The models were evaluated by employing different estimation techniques, although Panel Least Squares were selected as the preferred estimator. What is more, the fixed and random effects were included in order to evaluate the country-specific (time invariant) effect and time-specific (individual-invariant) effect. It has been established that the models with cross-section (country-specific) fixed effect were the most accurate in this case. The results of VAR models have been presented in Table 4, where significant parameters at $5 \%$ level have been marked with an asterisk $(*)$.

The results of VAR model

Table 4

\begin{tabular}{|c|c|c|c|}
\hline $\begin{array}{lll}\text { Independent variables } & \text { Dependent variables } \\
\end{array}$ & TRADE & GDP_capita & GDP_growth \\
\hline $\mathrm{C}$ & $-7,10654$ & $-7628,61$ & $35,2164 *$ \\
\hline TRADE & & 15,6178 & \\
\hline GDP_capita & $0,00172045^{*}$ & & $0,00117920 *$ \\
\hline GDP_growth & & $163,019 *$ & \\
\hline$R \& D$ & 5,67677 & $-1570,62$ & 0,750767 \\
\hline Services_VA & & & $-0,592364 *$ \\
\hline Industry & $1,38859^{*}$ & 51,3124 & \\
\hline Labour_PROD & 1,21213 & 44,6673 & 0,286166 \\
\hline TRADE(-1) & $0,748008^{*}$ & $-9,97144$ & \\
\hline
\end{tabular}




\begin{tabular}{|c|c|c|c|}
\hline \begin{tabular}{|ll} 
Independent variables & Dependent variables \\
\end{tabular} & TRADE & GDP_capita & GDP_growth \\
\hline GDP_capita(-1) & $-0,00297537^{*}$ & $0,855329^{*}$ & $-0,00246098^{*}$ \\
\hline GDP_growth(-1) & $-0,443328$ & 87,0536 & $0,318480^{*}$ \\
\hline FDI(-1) & $-0,0872443$ & & \\
\hline $\mathrm{R} \& \mathrm{D}(-1)$ & & 403,291 & \\
\hline Services_VA(-1) & & & $0,667284 *$ \\
\hline Industry(-1) & & 101,824 & \\
\hline Labour_PROD(-1) & 0,833528 & 717,822 & \\
\hline TRADE(-2) & $-0,0379213$ & 9,11196 & \\
\hline GDP_capita(-2) & $0,00170783^{*}$ & $-0,00561545$ & $0,000696851 *$ \\
\hline GDP_growth(-2) & $-0,225838$ & $-76,2064$ & 0,0244868 \\
\hline $\mathrm{R} \& \mathrm{D}(-2)$ & & 2388,99 & \\
\hline Services_VA(-2) & & & $-0,490893 *$ \\
\hline Industry(-2) & & 67,4373 & \\
\hline Labour_PROD(-2) & $-4,60727$ & $-104,332$ & \\
\hline TRADE(-3) & $-0,0367191$ & & 0,0103859 \\
\hline GDP_capita(-3) & $-0,000103954$ & 0,135514 & 0,000113674 \\
\hline GDP_growth(-3) & $-0,458615^{*}$ & $98,4699^{*}$ & $-0,210680^{*}$ \\
\hline$R \& D(-3)$ & & $-1482,53$ & \\
\hline Services_VA(-3) & & & $-0,0768680$ \\
\hline Labour_PROD(-3) & 2,50658 & $-735,959$ & \\
\hline LSDV R-squared & 0,969 & 0,974 & 0,768 \\
\hline
\end{tabular}

Source: compiled by the author

As it can be seen from Table 4, the precision of the first two models, in which the method of Least Squares Dummy Variables (LSDV) was applied, is very high, yet GDP_growth can be forecasted with lower precision. According to the results, GDP_capita of the same (current) time period and the last two years ( $t, t-1$ and $t-2)$, Industry_VA of the same time period $(t)$, GDP_growth three years ago $(t-3)$, and TRADE before a year $(t-1)$ are significant for prediction of TRADE of the current year. GDP_capita of the current time period and the last two years $(t, t-1$ and $t-2)$, Services_VA of the current time period and the last two years $(t, t-1$ and $t-2)$ as well as GDP_growth one and three years ago ( $t-1$ and $t-3)$ are significant for prediction of GDP_growth. Meanwhile, only GDP_growth of the current time period and three years ago ( $t$ and $t$-3) as well as GDP_capita before a year $(t-1)$ are significant for prediction of GDP_capita.

Considering the presence of many insignificant independent variables, the models were corrected by removing them one by one from the equation, starting from the most insignificant variable. The final significant VAR models can be expressed as follows:

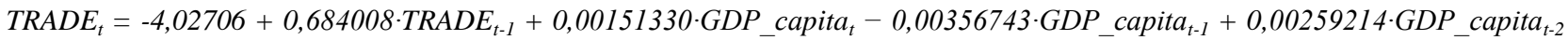
$-0,456009 \cdot G D P \_$growth $_{t-2}-0,544241 \cdot G D P \_$growth $_{t-3}+1,35991 \cdot \overline{I n d u s t r y}{ }_{-} V A_{t}$

GDP_capita $_{t}=-7283,64+0,943543 \cdot G D P$ capita $_{t-1}+209,701 \cdot G D P$ growth $_{t}+55,1358 \cdot G D P$ growth $_{t-1}-92,2368$

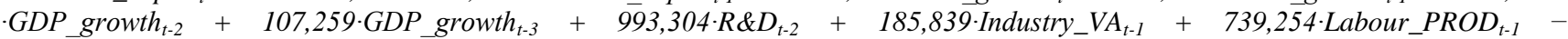
640,543.Labour_PROD

GDP_growth $t_{t}=34,907+0,357728+G D P$ _growth ${ }_{t-1}-0,219734 \cdot G D P \_$growth ${ }_{t-3}+$ 0,00127794.GDP_capita

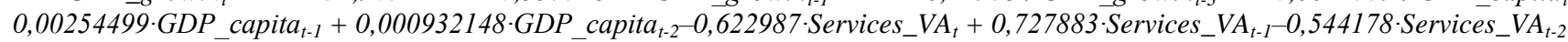

As the expressions above reveal, some new indicators, i.e. Industry_VA and Labour_PROD, have become significant for prediction of GDP_capita after correction of the model. LSDV R-squared of the first model is equal to 0,967 and respectively it accounts for 0,971 and 0,761 for the second and the third models.

It is obvious that TRADE to a great extent depends on TRADE of the previous year. Increase in Industry_VA as well as in GDP_capita also let boost TRADE, while GDP_growth of the previous year decreases it. Likewise, GDP_capita to a great extent depends on its value of the previous year. GDP_growth, as well as R\&D, Industry_VA and Labour_PROD of the previous year, have positive influence on GDP_capita. GDP_capita has, in general, more negative than positive impact on
GDP_growth. Negative impact of Services_VA on GDP_growth is caused by the fact that value added of services grew faster than GDP during the analysed period. Hence, the ratio of value added of services and GDP was growing, contrary to the trend of GDP_growth.

\section{Conclusions}

Theoretical studies on trade openness, economic growth and competitiveness cover a variety of the research on the weight of these variables and their impact on a country's economics in accordance with the provisions of the prevalent economic theories. Empirical studies commonly confirm positive interrelation among the variables mentioned above, but the results are obtained by 
employing different research techniques, samples and periods. Despite such variety of the studies on the linkages among trade openness, economic growth and competitiveness, trade openness is turning into the wide range of policies that shape a country's competitiveness and economic growth in the global markets.

The linkages among trade openness, economic growth and competitiveness were tested for 11 countries from Central and Eastern Europe by applying the methods of correlation analysis, Granger-causality test and VAR model. The correlation analysis has revealed that trade openness positively and significantly correlates with GDP per capita as well as with a series of indicators of competitiveness, i.e. R\&D expenditure, industry added value and labour productivity. The results show that the high-degree trade openness in CEEs provides the conditions relevant to economic growth and competitiveness increase in these countries.
Moreover, Granger-causality test as well as the developed VAR model have disclosed that economic growth has a long-lasting effect on trade openness. Competitiveness is related to economic growth by higher degree than it is linked to trade openness: GDP growth correlates with FDI, R\&D, services value added and labour productivity, while GDP per capita correlates with R\&D, industry value added and labour productivity. R\&D, industry and labour productivity have a long-lasting effect on GDP per capita in CEEs.

The results of the research have confirmed empirical interdependence among the triad components - trade openness, economic growth and competitiveness, i.e. it has been established that economic growth leads to the improvement of trade openness, while competitiveness of the CEE region leads to the improvement of economic growth, which has obviously disclosed the validity of the theoretical insights.

\section{References}

Abbas, S. (2014). Trade Liberalization and its Economic Impact on Developing and Least Developed Countries. Journal of International Trade Law and Policy, 13(3), 215-221. doi:10.1108/jitlp-06-2013-0018

Adhikary, B. K. (2010). FDI, Trade Openness, Capital Formation, and Economic Growth in Bangladesh: A Linkage Analysis. International Journal of Business and Management, 6(1). doi:10.5539/ijbm.v6n1p16

Berger, T. (2008). Concepts of National Competitiveness. Journal of International Business and Economy, 9(1), 91-111. Available from internet: http://www.i-jibe.org/achive/2008spring/5-Berger.pdf

Bruneckiene, J., \& Paltanaviciene, D. (2012). Measurement of Export Competitiveness of the Baltic States by Composite Index. Inzinierine Ekonomika-Engineering Economics, 23(1), 49-60. doi:10.5755/j01.ee.23.1.1218

Chang, R., Kaltani, L., \& Loayza, N. (2009), Openness is Good for Growth: The Role of Policy Complementarities, Journal of Development Economics, Vol. 90, pp. 33-49. doi:10.1016/j.jdeveco.2008.06.011

Clemens, M. A., \& Williamson, J. G. (2001). A Tariff-growth Paradox?: Protection's Impact the World Around 18751997, NBER working paper no. 8459. Cambridge, MA: NBER. Available from internet: http://www.nber.org/papers/w8459.pdf

Damijan, J. P., de Sousa, J., \& Lamotte, O. (2009). Does International Openness Affect Productivity of Local Firms? Evidence from Southeastern Europe. Economics of Transition, 17(3), 559-586. doi: 10.1111/j.1468-0351.2009.00361.x

Dollar, D., \& Kraay, A. (2003). Institutions, Trade, and Growth. Journal of Monetary Economics, 50(1), $133-162$. doi:10.1016/s0304-3932(02)00206-4

Dovis, M., \& Milgram-Baleix, J. (2009). Trade, Tariffs and Total Factor Productivity: The Case of Spanish Firms. World Economy, 32(4), 575-605. doi:10.1111/j.1467-9701.2009.01169.x

Dowrick, S. (2004). Trade Openness and Growth: Who Benefits? Oxford Review of Economic Policy, 20(1), 38-56. doi:10.1093/oxrep/grh003

Duczynski, P. (2000). Capital Mobility in Neoclassical Models of Growth: Comment. American Economic Review, 90(3), 687-694. doi:10.1257/aer.90.3.687

European Chamber. (2015). Trade Openness Index of European countries. Available from internet: http://eucham.eu/downloads/finish/132-eucham-charts/1807-2015-11-trade-openness-index-of-european-countries

Farmer, K., \& Schelnast, M. (2012). Factor Proportion, Inter-Sectoral Trade, and Product Life Cycle. Growth and International Trade, 215-233. doi:10.1007/978-3-642-33669-0_10

Granger, C. W. J. (2007). Spurious Regressions in Econometrics. A Companion to Theoretical Econometrics, $557-561$. doi:10.1002/9780470996249.ch27

Gries,T., \& Redlin, M. (2012). Trade Openness and Economic Growth: A Panel Causality Analysis. University of Paderborn, Germany. Available from internet: https://faculty.washington.edu/karyiu/confer/sea12/papers/SG12$112 \% 20$ Redlin.pdf

Guerrieri, P., \& Meliciani, V. (2005). Technology and International Competitiveness: The Interdependence between Manufacturing and Producer Services. Structural Change and Economic Dynamics, 16(4), 489-502. doi:10.1016/j.strueco.2005.02.002 
Hirsch, S. (2009). The Product Cycle Model of International Trade-A Multi-Country Cross-Section Analysis. Oxford Bulletin of Economics and Statistics, 37(4), 305-317. doi:10.1111/j.1468-0084.1975.mp37004004.x

Hwang, I., \& Wang, E. C. (2004). Does Openness to Trade Affect Total Factor Productivity Growth: Evidence from 45 Japanese Manufacturing Industries. Journal of Economic Research, 9, 147-173. Available from internet: http://jer.hanyang.ac.kr/issue/9_2/Hwang.pdf

Kane, J. (2003). Econometrics. Boston, MA: Houghton Mifflin.

Kim, E. (2000). Trade Liberalization and Productivity Growth in Korean Manufacturing Industries: Price Protection, Market Power and Scale Efficiency. Journal of Development Economics, 62(1), 55-83. doi:10.1016/S03043878(00)00075-4

Krugman, P. R. (1996). Making Sense of the Competitiveness Debate. Oxford Review of Economic Policy, 12(3), 17-25. doi:10.1093/oxrep/12.3.17

Liu, W., \& Nishijima, S. (2012). Productivity and Openness: Firm Level Evidence in Brazilian Manufacturing Industries. Economic Change and Restructuring, 46(4), 363-384. doi:10.1007/s10644-012-9131-6

Macher, J., \& Richman, B. (2008). Transaction Cost Economics: an Assessment of Empirical Research in the Social Sciences. Business and Politics, 10(1), 1-63. doi:10.2202/1469-3569.1210

Mauro, F., \& Forster, K. (2008). Globalisation and the Competitiveness of the Euro Area. ECB Occasional Paper Series No. 97. Available from internet: https://www.ecb.europa.eu/pub/pdf/scpops/ecbocp97.pdf

Miller, S. M., \& Upadhyay, M. P. (2000). The Effects of Openness, Trade Orientation, and Human Capital on Total Factor Productivity. Journal of Development Economics, 63(2), 399-423. doi:10.1016/s0304-3878(00)00112-7

Mulatu, A. (2016). On the Concept of 'Competitiveness' and its Usefulness for Policy. Structural Change and Economic Dynamics, March, 50-62. doi:10.1016/j.strueco.2015.11.001

Musila, J. W., \& Yiheyis, Z. (2015). The Impact of Trade Openness on Growth: The Case of Kenya. Journal of Policy Modeling, 37(2), 342-354. doi:10.1016/j.jpolmod.2014.12.001

Paul, S., \& Marks, A. (2009). Modelling Productivity Effects of Trade Openness: a Dual Approach. Australian Economic Papers, 48(2), 105-123. doi:10.1111/j.1467-8454.2009.00368.x

Porter, M. E. 1990. The Competitive Advantage of Nations. New York: Free Press. http://dx.doi.org/10.1007/978-1-34911336-1

Rath, B. N., \& Parida, P. C. (2014). Did Openness and Human Capital Affect Total Factor Productivity? Evidence from the South Asian Region. Global Journal of Emerging Market Economies, 6(2), 103-118. doi:10.1177/0974910114525535

Rebelo, S. (1991). Long-Run Policy Analysis and Long-Run Growth. Journal of Political Economy, 99(3), 500-521. doi:10.1086/261764

Reiljan, J., Hinrikus, M., \& Ivanov, A. (2000). Key Issues in Defining and Analysing the Competitiveness of a Country. Tartu: Tartu University Press. doi:10.2139/ssrn.418540

Reinert, E. S. (1995). Competitiveness and its Predecessors-a 500-year Cross-national Perspective. Structural Change and Economic Dynamics, 6(1), 23-42. doi:10.1016/0954-349x(94)00002-q

Remneland-Wikhamn, B., \& Knights, D. (2012). Transaction Cost Economics and Open Innovation: Implications for Theory and Practice. Creativity and Innovation Management, 21(3), 277-289. doi:10.1111/j.1467-8691.2012.00639.x

Romer, P. M. (1994). The Origins of Endogenous Growth. Journal of Economic Perspectives, 8(1), 3-22. doi:10.1257/jep.8.1.3

Sarkar, P. (2008). Trade Openness and Growth: Is There Any Link? Journal of Economic Issues, 42(3), $763-785$. doi:10.1080/00213624.2008.11507178

Singh, T. (2015). Trade Openness and Economic Growth in Canada: An Evidence from Time-Series Tests. Global Economy Journal, 15(3). doi:10.1515/gej-2014-0009

Snieska, V., \& Draksaite, A. (2007). The Role of Knowledge Process Outsourcing in Creating National Competitiveness in Global Economy. Inzinierine Ekonomika-Engineering Economics, (3), 35-41. Available from internet: http://www.inzeko.ktu.lt/index.php/EE/article/viewFile/12221/6806

Staskeviciute, G., \& Tamosiuniene, R. (2010). Salies konkurencingumas: sampratos raida laiko perspektyvoje. Verslas: Teorija Ir Praktika, 11(2), 159-167. doi:10.3846/btp.2010.18

Swanson, N. R. (2010). Further Developments in the Study of Cointegrated Variables. Journal of Financial Econometrics, 8(2), 187-190. doi:10.1093/jjfinec/nbq004 
Vaida Pilinkiene. Trade Openness, Economic Growth and Competitiveness. The Case of the Central and Eastern ...

Tahir, M., \& Azid, T. (2015). The Relationship Between International Trade Openness and Economic Growth in the Developing Economies. Journal of Chinese Economic and Foreign Trade Studies, 8(2), 123-139. doi:10.1108/jcefts02-2015-0004

Taylor, M. S., Grossman, G. M., \& Helpman, E. (1993). Innovation and Growth in the Global Economy. Economica, 60(239), 373. doi: $10.2307 / 2554862$

Ulasan, B. (2012). Openness to International Trade and Economic Growth: A Cross-Country Empirical Investigation. Economics Discussion Paper No. 2012-25. doi.org/10.2139/ssrn.2087930

Williamson, O. E. (1998). Transaction Cost Economics: How it Works; Where it is Headed. De Economist, 146(1), $23-58$. Available from internet: http://www.dqjj.com/bbs/UpLoadFile/2004-2/20042818365244698.pdf http://dx.doi.org/10. 1023/A:1003263908567

World Economic Forum. (2015). The Case for Trade and Competitiveness. Available from internet: http://www3.weforum.org/docs/WEF_GAC_Competitiveness_2105.pdf

Xu, H., Lai, M., \& Qi, P. (2008). Openness, Human Capital and Total Factor Productivity: Evidence from China. Journal of Chinese Economic and Business Studies, 6(3), 279-289. doi:10.1080/14765280802283576

Yanikkaya, H. (2003). Trade Openness and Economic Growth: a Cross-country Empirical Investigation. Journal of Development Economics, 72(1), 57-89. doi:10.1016/s0304-3878(03)00068-3

The article has been reviewed.

Received in January 2016; accepted in April, 2016. 